\title{
Exploring the Influence of Supply Chain Relationship Commitment and Loyalty in F\&B Industry
}

\author{
Jun-Zhi Chiu ${ }^{1}$ and Chao-Chen Hsieh ${ }^{2 *}$
}

\begin{abstract}
Recently, supply chain management (SCM)has been receiving increasing attention from the industry. Most of the current research is focused on the high-tech industry and very little research has focused on SCM topics in the food and beverage (F\&B) industry. In Taiwan, as the F\&B industry is highly competitive, maintaining and building strong relationships with suppliers of ingredients or tableware is a way to maintain a competitive edge. Therefore, maintaining and building strong relationships with suppliers of ingredients or tableware required for restaurant operations is a way to maintain a competitive advantage. In addition, the perceived value, relationship commitment, satisfaction, switching costs and loyalty of supply chain buyers in the F\&B industry is a matter that researchers want to probe when developing an ongoing understanding of SCM in the F\&B industry. It has been discovered that the supplier-buyer relationships, when it comes to buyer perceived value and relationship commitment, increase customer satisfaction and increase switching costs as well as positively impact loyalty to the F\&B supply chain seller. Therefore, in the rapidly dynamic business environment of the $\mathrm{F} \& \mathrm{~B}$ industry, establishing an effective SCM system for the F\&B industry can indeed enhance a company's competitive advantage.
\end{abstract}

JEL classification numbers: L10.

Keywords: Perceived value, Relationship commitment, Satisfaction, Loyalty.

${ }^{1}$ Department of Senior Citizen Service Management, Yuh-Ing Junior College of Health Care and Management, Taiwan.

2 Department of Marketing Management, Central Taiwan University of Science and Technology, Taiwan. ${ }^{*}$ Corresponding author.

Article Info: Received: December 14, 2021. Revised: January 14, 2022.

Published online: January 19, 2022. 


\section{Introduction}

According to a 2014 Commerce Operations Surveys Report from the Department of Statistics, Ministry of Economic Affairs. Taiwan's food and beverage (F\&B) industry broken through the 400 billion for three years with positive growth. In the past, the business regarded production management, production quality and marketing management as the factors of success. On the contrary, warehousing, packaging, transportation and distribution operations were not given as much attention. Along with changes in the operating environment and improvements in information technology, supply chain management has already transformed from the purchasing of raw materials, production, sales and even recycling into an important competence that businesses possess integration of supply and demand chain. It's made the businesses have more competitive advantages. Consequently, supply chain management is now an important strategic factor in successful business operations.

The F\&B industry supply chain has already slowly transformed from the traditional transaction model into one which incorporates the concept of relationship marketing. The F\&B industry supply chain is extremely complex. According to a literature review, supply chain has mostly been exploring about the speed of transaction for the purpose of customer satisfaction and the reduction of inappropriate inventory and unnecessary waste in order to reduce operating costs. On the buyers' side, it is about the hope that the cooperating supplier will meet their expectations which supplier have professional knowledge and provide timely shipments with a spirit of full cooperation. This relationship of transaction behavior based on real contract's regulations. When problems occur, law suits or penalties will take place in accordance with the content of the contract; however, these contract regulations cannot establish relationships (Handfield and Bechtel, 2002). In the F\&B industry supply chain management is more concerned with convenient order placements, short lead times, zero shortage rate, small quantity of diverse delivery, specific delivery times, fresh ingredient management and product tracking services to boost competitiveness. These all depend on a high level of cooperation and maintenance of close relationships between members of the supply chain. As a result, the establishment of $F \& B$ industry supply chains receives much attention from academics and operators in the field. Within this realm, one area that is of particular interest is the relationship between the suppliers and the buyers. From the manufacturer to the customer, each member of the supply chain must cooperate and this is an important factor in the successful operation of the supply chain. As the F\&B firm faces unprecedentedly fierce competition, establishment of supply chain relationships is also gradually being emphasized; only with close cooperation can create the greatest value.

Chang \& Wildt (1994) pointed out that value can be regarded as a conclusion made about the perceived quality of the product when compared with price. Also, as the perceived value increases so does the willingness to consume. Therefore, the consumer's willingness to consume usually depends on the perceived value 
obtained by the consumer (Dodds et al., 1991). From the perspective of the supplier, the customer is already become the most important strategic resources; the key to maintaining customer relationships is stressed on the establishment of customer loyalty and further maintenance a long-term relationship with consumers (Webster, 1994). In addition, the relationship commitment of members in the supply chain sustains the continuous demand which produced by the mutual relationship; and if the members establish a good relationship, then the willingness of each party to continue to cooperate will increase. When competition in a market is fierce, the establishment of cooperative relations with partners is certainly important; however, markets are not unchanging. When a buyer is considering changing suppliers, in each case thought must be given to the switching cost (Jackson, 1985). This is similar to a factor that contributes to the competitiveness of the market environment; high switching costs will dissuade buyers from leaving their current supplier (Jones $\&$ Sasser, 1995). The switching of suppliers is an important indicator determined by the market's supply and demand. The buyers regard that after changing suppliers, the new supplier will provide greater performance value than the original supplier did; if there is no difference, then they will not switch suppliers (Xavier \& Ypsilanti, 2008). The switching cost is an important exit barrier factor in the cooperative relationship that exists between the buyer and seller (Weiss and Anderson, 1992). Jones, et al. (2000) discovered the phenomenon where "loyal customers are not satisfied and satisfied customers are not loyal". That is to say that when consumers are considering changing suppliers, they will compare the benefit and cost before and after switching, and if the cost of switching is greater than the benefit, that will create a barrier against switching suppliers and will reduce the chances of a switch. For instance, if a buyer perceives that the switching cost is high, it will give the supplier the ability to lock in the buyer (Bharadwaji and Menon, 1993). The lockin effect is created as a result of pursuing the lowest cost and underestimating the switching cost in the future. (Shapiro \& Varian, 1999). Hence, the switching cost creates reliance in the relationship between the supplier and buyer, causing the buyer to cautiously search for a strategy of balanced reliance. When the choices for partners to cooperate are fewer or the switching costs greater, the mutual reliance relationship becomes more pronounced and it will deepen the connection between the partners (Heide \& John, 1988).

The switching cost is represented by the expenses that must be covered by the consumer when changing from the originally company or supplier to another company or supplier. When examining issues related to the "switching cost", past research has used quantitative methods to explore elementary factors and mutual influences, with empirical analyses on its application in different areas (Weiss \& Anderson,1992; Nilssen, 1992; Benito et al., 1999; Sharma \& Patterson, 2000; Jones et al., 2002; Burnham et al., 2003; Sharma, 2003). In recent research about supply chain relationships often are referred to, where considerable resources and knowledge can be obtained from the cooperating party; moreover, when such supply chains are using appropriate methods of management, the resulting processes increase in efficiency (Bakker and Nichols, 1994). 
Additionally, agreements between cooperating parties are established on mutual cooperation and not on an individual pursuit of one's own interests (Boddy et al., 2000), so businesses should all the more have close cooperation with other companies, thus benefiting by lowering costs and increasing profits. The advantage primarily arises from the effective use of resources and the establishment of longlasting transaction specific investments (Williamson, 1979). When the level of product standardization is increased or the number of potential suppliers is greater, the buyer's switching cost will decrease and the transaction mechanisms will tend to governed models of market transaction. At the same time, it will also cause the partnering relationship to towards one of market transaction. On the other hand, when the depth of cooperation between parties increases, it will increase the buyer's switching cost, causing the buyer have to consider whether or not the partnering relationship in the supply chain is at a strategic partnership level.

However, regarding the research related to the switching cost and how to hold onto a buyer, most focus on B2C consumer products. Within this area, discussions on F\&B industry's B2B supply chain research is rare. Thus, this study indents to from the perspective of F\&B industry purchasing and supply chain management to examine the perceived value and relationship commitment, while using switching cost and satisfaction to serve as an intermediary factor to explore the influence that each factor has on buyer loyalty. The research results will help various business within the F\&B industry by providing a directional basis to follow when managing suppliers and when planning the best allocation efficiency of resources in the supply chain.

\section{Literature review \& propositions development}

\subsection{Supply Chain}

The up-, mid- and downstream companies in the supply chain coordinate their efforts with the ultimate objective of satisfying the needs of the end customers. Each level or partner of the supply chain plays a different role in the overall processes of meeting the customer's needs. If the supply chain is taken as a large unified system, then the up-, mid- and downstream units can be regarded as subsystems, with operation flowing through connected organizations. Each link in the chain examines the work-flow problems that exist between each company and the intimate relationship that exists between the companies works to improve the effectiveness of the supply chain. The rise of the supply chain primarily came as a result of gradual changes in the environment, with shorter product life cycle and globalized economic market formations (Beamon, 1998). The so-called supply chain refers to an integrated production processes that brings raw materials to a final product in the customer's hands. Many different companies make up the supply chain, including suppliers, manufacturers, logistics companies and retailers. The objective is to join the up- and downstream companies to form unified chain of supply and bring the greatest efficiency into play (Beamon, 1998; Tan et al., 1998). Chopra \& Meindl (2007) describe the supply chain as a dynamic flow of information, products, and 
cash that extends from the upstream suppler to the downstream customer. Christopher (1999) further defines the supply chain as the networks of organizations that are involved in the diverse processes and activities that generate service value for customer.

In recent years, as a result of rapid changes in the business environment, increases in customer service requirements, time compression and such trends as industry globalization and inter-company cooperation, the situation gradually moved to one in which the manufacturers, suppliers and customers began cooperating within a more intimate relationship. Through a network, the participating companies can share mutual information and capabilities, thereby creating environment-changing competitive advantages. Accordingly, this research defines the supply chain as a strategy of coordinated and cooperative integration of the operating procedures of inter-enterprise cross-functional units. The supply chain management objectives involve pursuing effective cooperation between companies, reducing lead-times and minimized production costs, while integrating the logistics of suppliers, manufacturers, and warehousing to obtain the competitive advantages in business, increase information transparency and reduce transaction costs.

\subsection{Perceived Value}

The perceived value model was first proposed by Monroe \& Krishnan (1985), claiming that customer's perception of the target price and the price is an indicator to evaluate perceived quality and perceived sacrifice. By comparing the perceived quality and perceived sacrifice, the customers will obtain a perceived value. If the perceived quality obtained is greater than the perceived sacrifice made, the consumer will have a positive perception of the product or service. Consequently, perceived value has a positive effect on the customers willingness to purchase the product. Monroe (1990) further defined perceived value as "a tradeoff between the quality or benefits [customers] perceive in the product relative to the sacrifice they perceived by paying the price". When the customers are evaluating value, they will use their perceived sacrifice, personal preferences and individuality as a basis. Therefore, different customers will not have the same perceived value for the same service (Bolton \& Drew, 1991). The perceived value serves as a basis for decision making in the purchasing processes for the customer, where the customer's perceived value is the evaluation results of a comparison between the perceived quality of the product and the price paid.

However, the perceived value is also regarded as a dimension which is not easily defined or measured (Woodruff, 1997). It is mainly built on equity theory (Oliver \& DeSarbo, 1988) where the perceived value is a combination of the entity attributes, service attributes and technical support (Monroe, 1990). The perceived sacrifice includes the monetary sacrifice (price) and the non-monetary sacrifice (transportation/collection costs, mental /psychic costs) (Zeithaml, 1988). Zeithaml (1988) also points out that certain products might have a high quality, but customers do not have the budget to purchase them (or are not willing to spend the money), 
thus the perceived value of these products or services will be less than those with lower quality which the customer can afford. When customers evaluate their choices, they will choose the one that will give them the highest perceived value. Furthermore, with respect to competition, if a company can pass on a more generous value to the customer, this will help them to generate a competitive advantage. In their research, Patterson \& Spreng (1997) discovered that perceived value is indeed an antecedent variable of satisfaction, showing a positive relationship. The higher the satisfaction level, the higher the willingness to purchase again. In sum, there is a positive relationship between perceived value and satisfaction level.

\subsection{Satisfaction}

Howard \& Sheth (1969) defines satisfaction based on the customer's appraisal and comparison of two components, arguing that satisfaction is a type of cognitive attitude regarding the question of whether the amount paid was suitable for the reward received. They saw satisfaction as the level to which the expected product benefit manifested itself. Oliver (1981) describes satisfaction as a type of postpurchase appraisal that includes emotional and cognitive components. While Churchill (1982) argued that satisfaction is a type of result derived from purchasing and using the item, where the customer compares the reward of the expected result and the investment cost. Selnes (1993) claims that satisfaction is a post-transaction assessment of a particular transaction. Fornell (1992), based on the particular transaction point of view, points out that satisfaction is a post-purchase evaluation by the customer with respect to a particular purchasing occasion or point after purchasing which can provide performance diagnostic information on a specific product or service. The satisfaction evaluation result is a type of attitude; if the evaluation and resultant attitude is in-line with the expectations that the customer originally had for the product or service, then he/she will feel satisfied. This situation of satisfaction will result in a positive attitude towards the product or service and have a further positive impact on future willingness to purchase.

From the above explanations it can be seen that satisfaction is a type of judgment and cognitive understanding by the customer that is derived from the degree of pleasure obtained from the product/service or purchasing experience during the consumption process. Therefore, satisfaction is a type of emotional reaction that occurs when the customer is satisfied. Patterson \& Spreng (1997) discovered that perceived value is indeed an antecedent variable of satisfaction, showing a positive relationship. The higher the satisfaction level, the higher the willingness to purchase again. Therefore, this research proposes that:

$\mathbf{H}_{1}$ : The higher perceived value of a customer in the supply chain, the higher the satisfaction level. 


\subsection{Switching Cost}

Prior related researches, Jackson (1985) proposed a concept of switching cost, defining it as the mental, physical and economic cost for the customer to change suppliers. The discrepancy created by switching cost will cause related products to see different results (Klemperer,1987).

In the research of Jones et al. (2002), coming from a generalized perspective, switching cost can be defined as the cost of changing from one supplier to another. Thus, the switching cost is regarded as an exit barrier that customers face in their service relationships. Burnham et al. (2003) argue that switching cost refers to the "one-time cost" that a customer incurs in the process of switching from one supplier to another. Therefore, the creation of the switching cost and the switching processes have a necessary relationship; however, the creation of the cost does not immediately appear at the time that the customer changes suppliers. Fornell (1992) claims that when customers believe it is "not worth" to switch suppliers, they have already considered the restraints of financial, social and psychological risks posed by the search costs, transaction costs, learning costs, consumer loyalty discounts, consumer habits, and emotional costs and cognitive effort.

The perceived value is a customer's evaluation of the overall usefulness of the product or service purchased and is a weighing of the benefit received and the cost expended (Zeithaml, 1988). If the customer's perceived value is greater, this means that the benefit that he/she gains is far greater than the cost incurred. If there is a desire to switch to another service provider, then the benefit that is currently being enjoyed would be lost, while the benefit that will be gained after the transition is not yet known, thus the switching cost increases.

\subsection{Relationship Commitment}

According to the scholarships, the two main factors that influence the long-term relationship that exists between customers and companies are trust and commitment (Mohr \& Nevin,1990; Anderson \& Weitz,1992; Kumar et al. 1995). Relationship commitment refers to the situation where, through the marketing cooperation process, companies and customers mutually believe that a continuous unbroken relationship is important and they are willing to put in the most effort to maintain this valuable relationship (Morgan \& Hunt, 1994). Neither side will seek out substitutes, and they will invest large amounts of resources into this relationship. Consequently, for the company, commitment represents the guarantee that both parties have towards cooperation, including the provision of resources and mutual assistance for collaborative projects. Huang (1998) conducted a nation-wide study on customers in America, dividing relationship commitment into "loyalty", "attachment", and "expectation of continuity". Thomson et al. (2005) research discovered that relationship commitment has a significant positive impact on satisfaction: as relationship commitment improves, satisfaction goes up.

This research will adopt the relationship commitment refer to Morgan \& Hunt (1994) described, where, through the marketing cooperation process, companies and 
customers mutually believe that a continuous unbroken relationship is important and they are willing to put in the most effort to maintain this valuable relationship. This definition has received support and confirmation from marketing scholars; while at the same time, tests have been conducted on the business-to-consumer relationship, which is closer to this study's focus on the relationship between various companies in the $\mathrm{F} \& \mathrm{~B}$ industry supply chain. Commitment is the most direct and the strongest factor related to the maintenance of relationships. Morgan \& Hunt (1994) argue that commitment is a continuous desire to maintain a relationship with the other party and is central to all interaction. Relationship commitment will reduce the willingness to leave and strengthen organizational citizenship behavior. Therefore, this study proposes that:

$\mathbf{H}_{2}$ : The higher the supply chain customer's perception of the supplier's relationship commitment, the higher the level of satisfaction.

Morgan \& Hunt's (1994) theory implies that the key mediating variables (KMV) in relationship marketing focuses on the commitment and confidence exhibited by the people in the relationship during relational transaction. The cost of terminating the relationship refers to the possible switching cost problems that arise when one party desires to end the partnership. Therefore, this research proposes that:

H3: The higher the commitment the customer in a supply chain has towards the supplier, the higher the switching cost.

\subsection{Loyalty}

Fornell (1992) discovered that the cost of developing a new customer relationship is four to five times that of maintaining a relationship with an existing one. Consequently, loyalty will allow businesses to enjoy a more stable market position and will reduce the sensitivity of the customer towards the price of the product. Additionally, this will translate into a cost for the consumer to change brands and create a customer loyalty towards the brand or company, which is the goal that all businesses strive after. Selnes (1993) believes that loyalty includes the customer's willingness to purchase the product or service in the future. While Parasuraman et al. (1994) define loyalty not only as the willingness to make a repeat purchase, but also as a willingness to recommend the company to other people. Oliver (1997) argues that changes in environment or marketing efforts made by competitors might induce potential switching behavior, while the customer may still be willing to show high levels of commitment to a company. In the future, if the customer makes a repeat purchase of the same product or service, this is regarded as a manifestation of loyalty, as true loyalty is a behavioral manifestation, while satisfaction is a type of attitude (Neal, 1999). In the context of the food and beverage industry, the establishment and cultivation of loyalty is not simply an important issue, rather it is one that is "critical" as the key factor to the business's sustainable development. Increasing loyalty levels is the single most important driving force behind the 
enhancement of long-term financial performance.

A majority of research indicates that if high switching cost customers are segmented out, then there is a high correlation between customer loyalty and customer satisfaction (Bloemer et al., 1998; Jones et al., 2000). Sharma \& Patterson (2000) further argue that as customer switching costs increase, the relationship that exists between the confidence and commitment of the customer will also increase. Therefore, the switching cost becomes a key intervening variable between a number of different constructs (for instance customer satisfaction or confidence) and loyalty. In the cooperative relationship that exists between buyer and seller, switching costs serve as an important exit barrier factor (Weiss \& Anderson, 1992). Jones et al. (2000) discovered a phenomenon where "loyal customers are not satisfied and satisfied customers are not loyal"; that is to say, when customers are considering changing suppliers, they will compare the benefits and costs before and after switching and if the cost is higher than the benefit, a barrier is thus established which will reduce the chances that the customers will make the switch.

Reichheld \& Sasser (1990) argue that customer satisfaction will cause customer loyalty to increase, meaning that customers will be more willing to return in the future. Satisfied customers will increase the number of times they purchase and the quantity; they are more loyal to a company, and customers with high levels of loyalty will be more willing to make repeat purchases, further allowing the company to have higher income and greater profit. Thus, this research proposes that:

$\mathbf{H}_{4}$ : The higher the satisfaction of a customer in the supply chain, the higher the level of loyalty.

Lee \& Feick (2001) argue that as perceived switching costs increase, the willingness to make a repeat purchase of the originally-purchased product will increase. Furthermore, the switching cost is the price that must be paid to switch from the supplier originally chosen to another supplier. Thus, the switching cost can increase customer loyalty and establish a barrier for other suppliers (Heide \& Weiss 1995). Therefore, this study proposes that: 
H5: The higher the perceived switching cost of customers in a supply chain, the higher the loyalty they will have towards the supplier.

Derived from the literature review and hypotheses presented above, Figure 1 below conveys a graphical representation of the proposed relationships explored in this research and around which empirical analysis is guided.

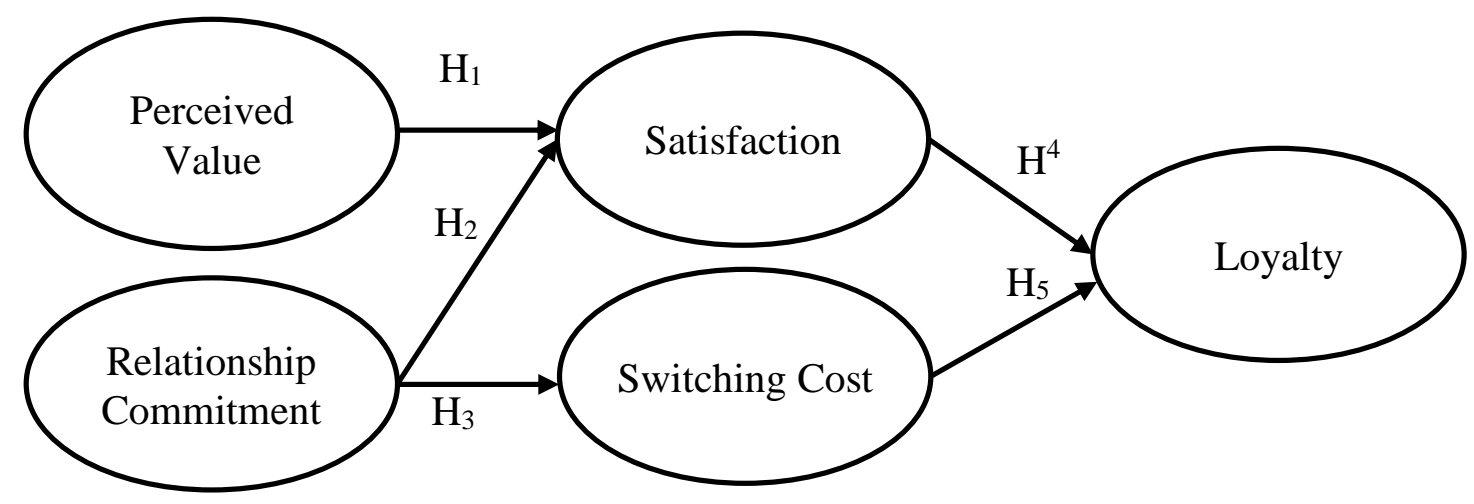

Figure 1: Proposed conceptual model

\section{Research methodology}

\subsection{Measures}

According to previous literature, we obtained the measures used in the study. We concluded that all scales were suitable and modify to fit our study and were valid and reliable measures of our constructs. A five-point Likert was employed for evaluating the constructs, with anchors ranging from strongly disagree (1), neither agree nor disagree (3), to strongly agree (5).

We adopt Petrick's (2002) Perceived Value Theory Scale, including time, cost and service used to measure the construct of perceiving values in the supply chain environment of the F\&B industry. As well as Morgan \& Hunt' $(1994 ; 1998)$ commitment-trust theory is used to measure the construct of relationship commitment. Satisfaction with suppliers is measured by the following items: quality of service, efficiency, and overall satisfaction with suppliers' supplier. We adopted a measure of supplier switching costs is defined by Jones et al. (2000), positive switching costs refer to relational and financial switching costs derived from adopting time. Finally, loyalty was measured with six items refer by the extant literature (Yang \& Peterson, 2004). Single-item questions were used to obtain data on gender, age, education, monthly revenue and frequency of procurement. 


\subsection{Sample and data collection procedure}

This study investigates the relationship between the various components of the supply chain in the Taiwans' F\&B industry by targeting the sourcing staff of the catering companies. It is considered that the buyers in the $\mathrm{F} \& \mathrm{~B}$ companies have more contact and interaction with suppliers; therefore, the buyers are used as the target of the questionnaire.

A two-stage cluster sampling design based on total assets of companies was used with 15 catering companies included in the first stage sampling frame. The 15 catering participating in this project provided a client list, and the second stage was dependent on the enrollment size. Every three buyer was selected using a systematic sampling method. The survey items were verified and refined for translation accuracy by three F\&B Management professors. The Chinese version of the draft was then pretested with $5 \mathrm{~F} \& \mathrm{~B}$ companies' managers for face and content validity, resulting in modifications of the wording of some survey items.

A total of 300 questionnaires were distributed to buyers along with a covering letter that explained the purpose and objectives of the study. A total of 274 usable questionnaires were returned, meaning a response rate of 91.3 percent. Table 1 lists the demographic information of the respondents.

Table 1: Sample description ( $N=274)$

\begin{tabular}{|c|c|c|c|}
\hline \multirow{4}{*}{ Gender } & $\begin{array}{c}\text { Demographic } \\
\text { characteristics }\end{array}$ & $\boldsymbol{N}$ & $\begin{array}{c}\text { Percentage } \\
\text { (\%) }\end{array}$ \\
\cline { 2 - 4 } & Male & 143 & $52.2 \%$ \\
\hline \multirow{4}{*}{ Age } & Female & 131 & $47.8 \%$ \\
\cline { 2 - 4 } & $21-30$ & 11 & $4.0 \%$ \\
\cline { 2 - 4 } & $31-40$ & 60 & $21.9 \%$ \\
\cline { 2 - 4 } & $41-50$ & 91 & $33.2 \%$ \\
\hline \multirow{4}{*}{ Education } & $>51$ & 81 & $29.6 \%$ \\
\cline { 2 - 4 } & High school or below & 31 & $11.3 \%$ \\
\cline { 2 - 4 } Frequency of & University & 143 & $33.9 \%$ \\
\cline { 2 - 4 } & Graduate school & 41 & $51.1 \%$ \\
\cline { 2 - 4 } & Day & 123 & $15 \%$ \\
\cline { 2 - 4 } & Weekly & 118 & $44.9 \%$ \\
\hline \multirow{4}{*}{$\begin{array}{c}\text { Mocurement } \\
\text { revenue }\end{array}$} & Quarterly & 24 & $43.1 \%$ \\
\cline { 2 - 4 } & 200,000 & 69 & $3.8 \%$ \\
\cline { 2 - 4 } & $200,000-300,000$ & 72 & $25.2 \%$ \\
\cline { 2 - 4 } & $300,000-400,000$ & 37 & $26.3 \%$ \\
\cline { 2 - 4 } & $400,000-500,000$ & 34 & $13.5 \%$ \\
\hline & $>500,000$ & 62 & $22.4 \%$ \\
\hline
\end{tabular}




\section{Data analysis and results}

\subsection{Model estimation}

The analysis was based on partial least square (PLS) path modeling using the SmartPLS 2.0 software (Ringle et al., 2005). The PLS technique is a powerful component-based method widely used in prior studies. The PLS analysis form of structural equation modeling, was used to test the conceptual model depicted in Figure 1.

\subsection{The measurement models}

Valid results, the reliability, convergent validity, and discriminant validity are essential for prerequisites to achieve the measurement model. The reliability (Brown, 2015) and convergent validity (Wang et al., 2015) of the scales was verified by using the three normal criteria: item reliability of each measure by using factor loading $>0.7$, Cronbach's $\alpha$ and composite reliability (CR) of each construct $>0.7$, and the average variance extracted (AVE) $>0.5$. As shown in Table 2 for convergent validity assessment, the standardized parameter loadings of measurement items range from 0.882 to 0.967 , which are in the acceptable range; in addition, the tvalues are significant at the 0.001 level. The Cronbach's $\alpha$ of the constructs ranges from 0.932 to 0.959 , and the CR ranges from 0.964 to 0.973 , both of which exceed the benchmark of 0.7 , thus confirming their reliability. Convergent validity can be assessed in terms of the AVE extracted from the latent variables. Table 2 show all latent variables had an AVE well above the commended value of 0.50 , ranging from 0.815 to 0.924 . 
Table 2: Results of the measurement model

\begin{tabular}{|c|c|c|c|c|}
\hline Construct items & Factor loading & Cronbach's $\alpha$ & CR & AVE \\
\hline Perceived Value (PV) & & 0.955 & 0.964 & 0.815 \\
\hline PV1 & 0.905 & & & \\
PV2 & 0.897 & & & \\
PV3 & 0.882 & & & \\
PV4 & 0.934 & & & \\
PV5 & 0.907 & & & \\
PV6 & 0.893 & & 0.973 & 0.924 \\
\hline Satisfaction (Sat) & & 0.959 & & \\
\hline Sat1 & 0.953 & & & \\
Sat2 & 0.967 & & \\
Sat3 & 0.963 & & & \\
\hline Switching Cost (SC) & & 0.932 & 0.957 & 0.880 \\
\hline SC1 & 0.928 & & & \\
SC2 & 0.941 & & & \\
SC3 & 0.946 & & 0.965 & 0.901 \\
\hline Relationship & & 0.945 & & \\
Commitment (RC) & & & \\
\hline RC1 & 0.934 & & & \\
RC2 & 0.965 & & & \\
RC3 & 0.949 & & & \\
\hline Loyalty (Loy) & & 0.955 & 0.964 & 0.816 \\
\hline Loy1 & 0.904 & & & \\
Loy2 & 0.885 & & & \\
Loy3 & 0.883 & & & \\
Loy4 & 0.917 & & & \\
Loy5 & 0.913 & & & \\
Loy6 & 0.918 & & & \\
\hline Soys & & & \\
\hline
\end{tabular}

Notes: Factor loadings above 0.5 are highlighted in italics. All t-values of italic values are $\mathrm{p}<0.001$ 
To test the discriminant validity (Wang et al., 2015), we check factor loadings and cross-loadings that are shown in Table 3. All items have higher loadings on their respective constructs than their cross-loadings with other constructs, supporting the discriminant validity. As an additional way to judge the discriminant validity.

Table 3: Item loading and cross-loading

\begin{tabular}{|l|c|c|c|c|c|c|}
\hline \multirow{4}{*}{ Construct } & Items & $\mathbf{1}$ & $\mathbf{2}$ & $\mathbf{3}$ & $\mathbf{4}$ & $\mathbf{5}$ \\
\hline \multirow{4}{*}{$\begin{array}{l}\text { 1. Perceived } \\
\text { Value }\end{array}$} & PV1 & $\mathbf{0 . 9 0 5}$ & 0.653 & 0.571 & 0.691 & 0.726 \\
\cline { 2 - 7 } & PV2 & $\mathbf{0 . 8 9 7}$ & 0.647 & 0.568 & 0.689 & 0.760 \\
\cline { 2 - 7 } & PV3 & $\mathbf{0 . 8 8 2}$ & 0.731 & 0.681 & 0.734 & 0.768 \\
\cline { 2 - 7 } & PV4 & $\mathbf{0 . 9 3 4}$ & 0.741 & 0.654 & 0.782 & 0.812 \\
\cline { 2 - 7 } & PV5 & $\mathbf{0 . 9 0 7}$ & 0.658 & 0.564 & 0.746 & 0.757 \\
\cline { 2 - 7 } & PV6 & $\mathbf{0 . 8 9 3}$ & 0.680 & 0.644 & 0.749 & 0.782 \\
\hline \multirow{4}{*}{ 2. Satisfaction } & Sat1 & 0.701 & $\mathbf{0 . 9 5 3}$ & 0.512 & 0.675 & 0.680 \\
\cline { 3 - 7 } & Sat2 & 0.724 & $\mathbf{0 . 9 6 7}$ & 0.521 & 0.714 & 0.715 \\
\cline { 2 - 7 } & Sat3 & 0.765 & $\mathbf{0 . 9 6 3}$ & 0.588 & 0.776 & 0.760 \\
\hline \multirow{3}{*}{ 3. Switching Cost } & SC1 & 0.658 & 0.541 & $\mathbf{0 . 9 2 8}$ & 0.603 & 0.614 \\
\cline { 2 - 7 } & SC2 & 0.628 & 0.520 & $\mathbf{0 . 9 4 1}$ & 0.604 & 0.588 \\
\cline { 2 - 7 } & SC3 & 0.633 & 0.524 & $\mathbf{0 . 9 4 6}$ & 0.590 & 0.589 \\
\hline \multirow{3}{*}{ 4. Relationship } & RCl & 0.718 & 0.696 & 0.616 & $\mathbf{0 . 9 3 4}$ & 0.749 \\
\cline { 2 - 7 } & RC2 & 0.807 & 0.719 & 0.617 & $\mathbf{0 . 9 6 5}$ & 0.795 \\
\cline { 2 - 7 } & RC3 & 0.786 & 0.728 & 0.584 & $\mathbf{0 . 9 4 9}$ & 0.791 \\
\hline \multirow{4}{*}{ 5ommitment } & Loy 1 & 0.752 & 0.661 & 0.545 & 0.728 & $\mathbf{0 . 9 0 4}$ \\
\cline { 2 - 7 } & Loy 2 & 0.716 & 0.624 & 0.591 & 0.702 & $\mathbf{0 . 8 8 5}$ \\
\cline { 2 - 7 } & Loy 3 & 0.710 & 0.626 & 0.590 & 0.748 & $\mathbf{0 . 8 8 3}$ \\
\cline { 2 - 7 } & Loy 4 & 0.791 & 0.713 & 0.558 & 0.750 & $\mathbf{0 . 9 1 7}$ \\
\cline { 2 - 7 } & Loy 5 & 0.811 & 0.708 & 0.594 & 0.744 & $\mathbf{0 . 9 1 3}$ \\
\cline { 2 - 7 } & Loy 6 & 0.825 & 0.721 & 0.573 & 0.771 & $\mathbf{0 . 9 1 8}$ \\
\hline
\end{tabular}


As shown in Table 4, each square root value of average variance extracted (AVE, Hair et al., 2019) is greater than the inter-factor correlations.

Table 4: Discriminant validity for the measurement model

\begin{tabular}{|cl|c|c|c|c|c|c|c|}
\hline & & Mean & SD & $\mathbf{1}$ & $\mathbf{2}$ & $\mathbf{3}$ & $\mathbf{4}$ & $\mathbf{5}$ \\
\hline 1. & Perceived Value & 3.837 & 0.954 & 0.903 & & & & \\
\hline 2. & Satisfaction & 3.694 & 1.026 & 0.761 & 0.961 & & & \\
\hline 3. & Switching Cost & 3.551 & 1.058 & 0.682 & 0.564 & 0.938 & & \\
\hline 4. & $\begin{array}{l}\text { Relationship } \\
\text { Commitment }\end{array}$ & 3.637 & 1.052 & 0.812 & 0.753 & 0.638 & 0.949 & \\
\hline 5. & Loyalty & 3.681 & 0.949 & 0.851 & 0.749 & 0.637 & 0.820 & 0.903 \\
\hline
\end{tabular}

Note: Italic values represent the square root of the AVE for each construct

Thus, we conclude that each construct including perceived value, satisfaction, switching cost, relationship commitment, loyalty all are distinct from others. In other words, the result indicated a good degree of unidimensionality for each construct.

\subsection{The structural model}

The bootstrapping procedures with 500 replications in PLS was used to estimate the structural model and test the hypotheses. As shown in Table 5, all hypotheses were significant, at least at the 0.001 level, strongly supporting the proposed research model.

Table 5: Hypothesis test results

\begin{tabular}{|c|c|c|c|c|}
\hline Hypothesis & Path & $\begin{array}{c}\text { Path } \\
\text { coefficient }\end{array}$ & $t$-value & Results \\
\hline$H_{1}$ & $\begin{array}{c}\text { Perceived Value } \\
\rightarrow \text { Satisfaction }\end{array}$ & $0.439^{* * *}$ & 4.903 & Supported \\
\hline$H_{2}$ & $\begin{array}{c}\text { Relationship Commitment } \\
\rightarrow \text { Satisfaction }\end{array}$ & $0.572^{* * *}$ & 4.381 & Supported \\
\hline$H_{3}$ & $\begin{array}{c}\text { Relationship Commitment } \\
\rightarrow \text { Switching Cost }\end{array}$ & $0.314^{* * *}$ & 14.619 & Supported \\
\hline$H_{4}$ & Satisfaction $\rightarrow$ Loyalty & $0.397^{* * *}$ & 10.671 & Supported \\
\hline$H_{5}$ & Switching Cost $\rightarrow$ Loyalty & $0.638^{* * *}$ & 6.119 & Supported \\
\hline Notes: $\quad{ }^{* * * *} p<0.001$ & & \\
\hline
\end{tabular}


Additionally, path coefficients of the research model is shown in Figure 2.

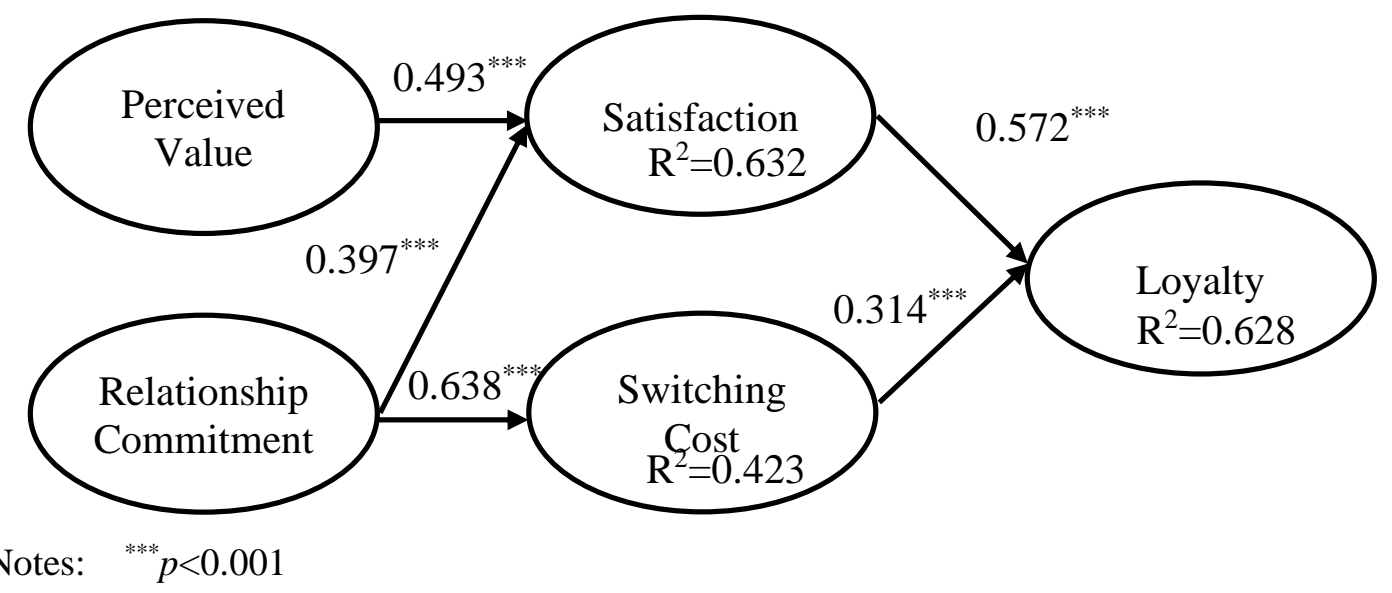

Figure 2: Path coefficients of the research model

$\mathrm{H}_{1}$ posits that perceived value of a customer in the supply chain, the higher the satisfaction level. Meanwhile, it can be observed that the path coefficient is $0.493(\mathrm{P}<0.001)$ thus supporting $\mathrm{H}_{1}$. As well as the link between perceived relationship commitment and satisfaction $\left(\mathrm{H}_{2}\right)$ was significant at the 0.001 level with a path coefficient of $0.572 . \mathrm{H}_{3}$, which states that relationship commitment affects switching cost, is confirmed $(\beta=0.314, \mathrm{P}<0.001)$. The effect of satisfaction on the loyalty has been found to be significant $(\beta=0.397, \mathrm{P}<0.001)$, thus supporting $\mathrm{H}_{4}$. Furthermore, the result shows the positive influence of switching cost on the loyalty $(\beta=0.638, \mathrm{P}<0.001)$, thereby confirming $\mathrm{H}_{5}$.

\section{Conclusions}

According to our study, the perceived value of a restaurant buyer is indeed an antecedent variable of satisfaction and is positively and significantly related to the higher the satisfaction level, the higher the loyalty to the supplier. The results of the study show that a high perceived value of a F\&B supply chain partnership positively and significantly affects the satisfaction of its suppliers.

In addition, satisfied customers increase their purchase frequency and volume of purchases Reichheld \& Sasser (1990) suggest that those who are satisfied with the service of a supplier in the F\&B supply chain have a higher level of loyalty, which in turn increases their willingness to make repeat purchases, leading to higher revenue and increased profitability for the company. In the F\&B supply chain, if buyers recognize the high switching costs of switching to another supplier, they will be less likely to switch suppliers, increasing their loyalty to the original supplier. From relationship practices, it is found that relationship commitment is a mutual belief in the importance of an ongoing relationship and a willingness to do their best to maintain this valuable relationship (Morgan \& Hunt, 1994). Therefore, the supply 
and procurement partners in the F\&B supply chain do not easily seek alternative partners and both parties invest a lot of resources in maintaining the relationship (Sharma \& Patterson, 2000). Therefore, for a company, a commitment represents a guarantee of cooperation between two parties in the supply chain, including the provision of resources. Therefore, when buyers in the supply chain perceive a high level of commitment to the relationship, they will positively increase their satisfaction with the supplier.

However, the higher the expected switching costs for the buyer, the greater the willingness to maintain an experienced relationship with the original supplier (Crosby et al., 1990; Dwyer et al., 1987; Kumar et al., 1995). For buyers with a high willingness to establish relationships with regular staff, interaction with regular staff is chosen or expected because frequent interaction with specific staff provides an opportunity to build emotional trust between customers and service staff (Johnson \& Grayson, 2005). Therefore, buyers' perceived high commitment to relationships within the F\&B supply chain increases their switching costs.

Maintaining customer loyalty is an important issue in supply chain management and is regarded as an important source of competitiveness for businesses. This study explored the perceived value and relationship commitment F\&B industry supply chain customers have towards suppliers, considering the intermediary effects of switching cost and satisfaction, which positively impact customer loyalty towards suppliers, also clarifying the relationship between the various facets to provide a positive research direction for $\mathrm{F} \& \mathrm{~B}$ industry supply chain management issues.

\section{Reference}

[1] Anderson, E. and Weitz, B. (1992). The use of pledges to build and sustain commitment in distribution channels. Journal of Marketing Research, 29(1), 18-34.

[2] Bakker, H. and Nichols, M. (1994). Using core competence to develop new business. Long Range Planning, 27(6), 13-27.

[3] Beamon, B. M. (1998). Supply chain design and analysis: Models and methods. International Journal of Production Economics, 55(3), 281-294.

[4] Benito, G. R. G, Pedersen, T. and Petersen, B. (1999). Foreign operation methods and switching costs: conceptual issues and possible effects. Scandinavian Journal of Management, 15(2), 213-229

[5] Bharadwaji, S. G. and Menon, A. (1993). Determinants of success in service industries: A PIMS-based empirical investigation. The Journal of Services Marketing, 7(4), 19-40.

[6] Bloemer, J., De Ruyter, K. and Peeters, P. (1998). Investigating drivers of bank loyalty: The complex relationship between image, service quality and satisfaction. International Journal of Bank Marketing, 16(7), 276-286.

[7] Boddy, D., Macbeth, D. and Wagner, B. (2000). Implementing collaboration between organizations: An empirical study of supply chain partnering. Journal of Management Studies, 37(7), 1003-1017. 
[8] Bolton, R. N. and Drew, J. H. (1991). A longitudinal analysis of the impact of service changes on customer attitudes. The Journal of Marketing, 55(1), 1-9.

[9] Brown, T. A. (2015). Confirmatory factor analysis for applied research. Second Edition. New York: The Guilford Press.

[10] Burnham, T. A., Frels, J. K. and Mahajan, V. (2003). Consumer switching costs: A typology, antecedents, and consequences. Journal of the Academy of Marketing Science, 31(2), 109-126.

[11] Chang, T. Z. and Wildt, A. R. (1994). Price, product information, and purchase intention: an empirical study. Journal of the Academy of Marketing Science, 22(1), 16-27.

[12] Chopra, S., and Meindl, P. (2007). Supply chain management. Strategy, planning \& operation. In Das summa summarum des management (265-275). Gabler.

[13] Christopher, M. (1999). Logistics and supply chain management: Strategies for reducing cost and improving service financial times: Pitman Publishing. London.

[14] Churchill Jr, G. A. and Surprenant, C. (1982). An investigation into the determinants of customer satisfaction. Journal of Marketing Research, 19(4), 491-504.

[15] Dodds, W. B., Monroe, K. B. and Grewal, D. (1991). Effects of price, brand, and store information on buyers, product evaluations. Journal of Marketing Research, 28(3), 307-319.

[16] Fornell, C. (1992). A national customer satisfaction barometer: The swedish experience. The Journal of Marketing, 56(1), 6-21.

[17] Hair, J.P., Black, J.P., Babin, J.P., and Anderson, R.E. (2019). Multivariate data analysis, eighth edition. Harlow: Cengage Learning.

[18] Handfield, R. B. and Bechtel, C. (2002). The role of trust and relationship structure in improving supply chain responsiveness. Industrial Marketing Management, 31(4), 367-382.

[19] Heide, J. B. and John, G. (1988). The role of dependence balancing in safeguarding transaction-specific assets in conventional channels. The Journal of Marketing, 52(1), 20-35.

[20] Heide, J. B. and Weiss, A. M. (1995). Vendor consideration and switching behavior for buyers in high-technology markets. The Journal of Marketing, 59(3), 30-43.

[21] Howard, J. D. and Sheth, J.N. (1969). The theory of buyer behavior. New York, John Wiley \& Sons.

[22] Huang, P. F. (1998). Relationship marketing: Investigation into consumers' initiation, maintenance and adjustment/disengagement of marketing relationship. Business Administration, The University of Mississippi.

[23] Jackson, B. B. (1985). Build customer relationships that last. Harvard Business Review, 63, 120-128.

[24] Jones, M. A., Mothersbaugh, D. L. and Beatty, S. E. (2000). Switching barrier and repurchase intentions in services. Journal of Retailing, 76(2) 259-274. 
[25] Jones, M.A., Mothersbaugh, D. and Beatty, S. (2002). Why customers stay: Measuring the underlying dimensions of services switching costs and managing their differential strategic outcomes. Journal of Business Research 55(6): 441-450

[26] Jones, T. O. and Sasser, W. E., Jr. (1995). Why satisfied customers defect. Harvard business review, 73(6), 88.

[27] Klemperer, P. (1987). Markets with Consumer Switching Costs. The Quarterly Journal of Economics, 102(2), 375-394.

[28] Kumar, N., Scheer, L. K. and Steenkamp, J. B. E. (1995). The effects of perceived interdependence on dealer attitudes. Journal of Marketing Research, 32(3), 348-356.

[29] Lee, J. and Feick, L. (2001). The impact of switching costs on the customer satisfaction-loyalty link: Mobile phone service in France. Journal of Services Marketing, 15(1), 35-48.

[30] Mohr, J. and Nevin, J. R. (1990). Communication strategies in marketing channels: A theoretical perspective. The Journal of Marketing, 54(4), 36-52.

[31] Monroe, K. B. \& Krishnan, R. (1985). The effect of price on subjective product evaluations. Perceived Quality, 1, 209-232.

[32] Monroe, K. B. (1990). Pricing: Making profitable decisions, New York: McGraw-Hill Book Company.

[33] Morgan, R. M. and Hunt, S. D. (1994). The commitment-trust theory of relationship marketing. The Journal of Marketing, 58(3), 20-38.

[34] Neal, W. D. (1999). Satisfaction is nice, but value drives loyalty. Marketing Research, 11(1), 21-23.

[35] Nilssen, T. (1992). Two kinds of consumer switching costs. The Rand Journal of Economics, 23(4), 579-589.

[36] Oliver, C. (1997). Sustainable competitive advantage: Combining institutional and resource-based views. Strategic Management Journal, 18(9), 697-713.

[37] Oliver, R. L. (1981). Measurement and evaluation of satisfaction processes in retail settings. Journal of Retailing, 57, 95-48.

[38] Oliver, R. L. and DeSarbo, W. S. (1988). Response determinants in satisfaction judgments. Journal of Consumer Research, 14, 495-507.

[39] Parasuraman, A., Zeithaml, V. A. and Berry, L. L. (1994). Reassessment of expectations as a comparison standard in measuring service quality: Implications for further research. The Journal of Marketing, 58(1), 111-124.

[40] Patterson, P. G. and Spreng, R. A. (1997). Modelling the relationship between perceived value, satisfaction and repurchase intentions in a business-tobusiness, services context: An empirical examination. International Journal of Service Industry Management, 8(5), 414-434.

[41] Petrick, J. F. (2002). Development of a multi-dimensional scale for measuring the perceived value of a service. Journal of Leisure Research, 34(2), 119-134.

[42] Reichheld, F. P. and Sasser, W. E. (1990). Zero defections: Quality comes to services. Harvard Business Review, 68(5), 105-111. 
[43] Selnes, F. (1993). An examination of the effect of product performance on brand reputation, satisfaction and loyalty. Journal of Product \& Brand Management, 2(4), 45-60.

[44] Shapiro C. and Varian, H. R. (1999). Information rules: A strategic guide to the network economy. Harvard Business Press.

[45] Sharma, N. (2003). The role pure and quasi-moderators in services: An empirical investigation of ongoing customer services provider relationship. Journal of retailing and Consumer Services.10 (4). 253-62.

[46] Sharma, N. and Patterson, P.G. (2000). Switching costs, alternative attractiveness and experience as moderators of relationship commitment in professional, consumer services. International Journal of Service Industry Management, 11(5), 470-490.

[47] Tan, K. C., Kannan, V. R. and Handfield, R. B. (1998). Supply chain management: Supplier performance and firm performance. Journal of Supply Chain Management, 34(3), 2-9.

[48] Thomson, M., Macinnis, D. J., and Park, C. W. (2005). The ties that bind: measuring the strength of consumers' emotional attachments to brands. Journal of Consumer Psychology, 15(1), 77-91.

[49] Wang, X., French, B. F., and Clay, P. F. (2015). Convergent and discriminant validity with formative measurement: A mediator perspective. Journal of Modern Applied Statistical Methods, 14(1), 83-106.

[50] Webster, F. E. Jr. (1994). Executing the New Marketing Concept. Marketing Management, 3(1), 9-18.

[51] Weiss, A. M. and Anderson, E. (1992). Converting from independent to employee salesforces: The role of perceived switching costs. Journal of Marketing Research, 101-115.

[52] Williamson, O. E. (1979). Transaction-cost Economics: The Governance of Contractual Relations. Journal of law and economics, 233-261.

[53] Woodruff, R. B. (1997). Customer value: the next source for competitive advantage. Journal of the Academy of Marketing Science, 25(2), 139-153.

[54] Xavier, P. and Ypsilanti, D. (2008). Switching Costs and Consumer Behavior: Implications for Telecommunications Regulation. Info, 10(4), 13-29.

[55] Yang, Z. and Peterson, R. T. (2004). Customer Perceived Value, Satisfaction, and Loyalty: The Role of Switching Costs. Psychology \& Marketing, 21(10), 799-822.

[56] Zeithaml, V. A. (1988). Consumer Perceptions of Price, Quality, and Value: A Means-End Model and Synthesis of Evidences. Journal of Marketing, 52 (3),222.

\section{ACKNOWLEDGEMENTS.}

This work was supported by the National Science Council, Taipei, Taiwan, R.O.C., Project No. Grant MOST: 104-2622-E-328-001-CC3. 